\title{
The effects of local culture on hospital administration in West Sumatra, Indonesia by Rima Semiarty
}

Submission date: 09-Nov-2019 10:20AM (UTC+0800)

Submission ID: 1210153004

File name: Jurnal-dr.Rima1.pdf (123.86K)

Word count: 5662

Character count: 30654 


\section{eemeraldinsight}

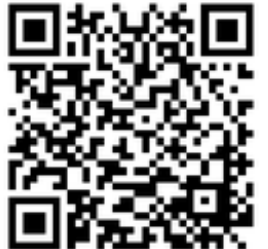

\section{Leapdership in Health Services}

The effects of local culture on hospital administration in West Sumatra, Indonesia

Rima Semiarty Rebecca Fanany

\section{Article information:}

To cite this document:

Rima Semiarty Rebecca Fanany , (2017),"The effects of local culture on hospital administration in

West Sumatra, Indonesia ", Leadership in Health Services, Vol. 30 Iss 1 pp. $59-67$

Permanent link to this document:

http://dx.doi.org/10.1108/LHS-01-2016-0001

Downloaded on: 01 February 2017, At: 18:04 (PT)

References: this document contains references to 21 other documents.

To copy this document: permissions@emeraldinsight.com

The fulltext of this document has been downloaded 11 times since $2017^{*}$

\section{Users who downloaded this article also downloaded:}

(2017),"Dual leadership in a hospital practice", Leadership in Health Services, Vol. 30 Iss 1 pp. 101-112 http://dx. doi.org/10.1108/LHS-09-2015-0030

(2017),"Healthcare leadership's diversity paradox", Leadership in Health Services, Vol. 30 Iss 1 pp. 68-75 http://dx.doi.org/10.1108/LHS-02-2016-0007

\section{NM \\ STATE \\ Library}

Access to this document was granted through an Emerald subscription provided by emeraldsim: 199044 []

\section{For Authors}

If you would like to write for this, or any other Emerald publication, then please use our Emerald for Authors service information about how to choose which publication to write for and submission guidelines are available for all. Please visit www. emeraldinsight.com/authors for more information.

\section{About Emerald www.emeraldinsight.com}

Emerald is a global publisher linking research and practice to the benefit of society. The company manages a portfolio of more than 290 journals and over 2,350 books and book series volumes, as well as providing an extensive range of online products and additional customer resources and services.

Emerald is both COUNTER 4 and TRANSFER compliant. The organization is a partner of the Committee on Publication Ethics (COPE) and also works with Portico and the LOCKSS initiative for digital archive preservation.

*Related content and download information correct at time of download. 


\title{
The effects of local culture on hospital administration in West Sumatra, Indonesia
}

\author{
Rima Semiarty \\ Universitas Andalas, Padang, Indonesia, and \\ Rebecca Fanany \\ School of Humanities and Social Sciences, Deakin University, \\ Melbourne, Australia
}

Effects of local

culture

Abstract

Purpose - Problems in health-care leadership are serious in West Sumatra, Indonesia, especially in hospitals, which are controlled locally. The purpose of this paper is to present the experience of three hospitals in balancing the conflicting demands of the national health-care system and the traditional model of leadership in the local community.

Design/methodology/approach - Three case studies of the hospital leadership dynamic in West Sumatra were developed from in-depth interviews with directors, senior administrators and a representative selection of employees in various professional categories,

Findings - An analysis of findings shows that traditional views about leadership remain strong in the community and color the expectations of hospital staff. Hospital directors, however, are bound by the modern management practices of the national system. This conflict has intensified since regional autonomy which emphasizes the local culture much more than in the past.

Research limitations/implications - The research was carried out in one Indonesian province and was limited to three hospitals of different types.

Practical implications - The findings elucidate a potential underlying cause of problems in hospital management in Indonesia and may inform culturally appropriate ways of addressing them.

Originality/value - The social and cultural contexts of management have not been rigorously studied in Indonesia. The relationship between local and national culture reported here likely has a similar effect in other parts of the country.

Keywords Hospitals, Leadership, Indonesia, Local culture

Paper type Case study

\section{Introduction}

Regional autonomy, which took effect in Indonesia in 2001, has affected virtually every aspect of administration at all levels of government. This new autonomy assigns the responsibility for multiple services and administrative functions to the local government, including health care. One of the main difficulties in implementing regional autonomy has been the lack of experienced personnel in the autonomous regions. In the past, a highly centralized system drew talented and ambitious individuals to the capital Jakarta. Regional autonomy created a need to attract experienced administrators back to their regions of origin and has also created a form of favoritism in hiring where individuals native to the region have a significant advantage. As a result, local culture now plays a much greater role in the public environment. In the past, the distinction between the public context, associated with use of the national language and a national culture, and the informal context, where local languages and cultures dominated, was clear (Fanany and Effendi, 1999). While it is 
LHS

30,1

60

suspected that local culture has a significant effect on health-care leadership, this issue has not been widely studied, either in general or specifically in Indonesia.

\section{Health care in Indonesia under regional autonomy}

Before regional autonomy, many programs were run by health centers, operating at the district level, while the health offices at the regional level served mainly as conduits for information between provincial health departments and lower-level components (Tjiptoherijanto and Soesetyo, 1994). In 2004, a new Regional Health Care System replaced the existing system with standards of care that were determined by the Minister of Health and complemented Indonesia's Millennium Development Goals for Health. One of the most serious challenges in the system's implementation was to ensure appropriate funding for health care in each region whose capacity varied considerably (Trisnantoro, 2001).

Since regional autonomy, it has been difficult to maintain existing health-care institutions because of funding and also staffing and leadership (Kristiansen and Santoso, 2006). It has been difficult for public hospitals to attract specialists, who often work extensively in the private sector in addition to their public position because of the earning potential (Meliala et al.,2013). Hospital accreditation has been a particular problem, despite a National Hospital Accreditation Commission (Komisi Akreditasi Rumah Sakit, KARS) being set up in 1998 (Hort et al., 2013). KARS itself is accredited by the International Society for Quality in Health Care (KARS, 2015). In 2010, the Ministry of Health and KARS introduced a new set of standards based on the US Joint Commission International Framework (Joint Commission International, 2015). Accreditation is based on the standards described in this framework that include international outcome metrics, such as bed occupancy rate (BOR), bed turnover (BTO) and average length of stay (ALOS).

To date, there has been no rigorous study of the ways in which these changes in the local context since regional autonomy have affected the management and operations of hospitals in Indonesia. In particular, the effect of the tension between the local culture and the national context, which is suspected to be significant in the quality of services, has not been studied. The current study investigates this issue in West Sumatra.

\section{The West Sumatran context}

The province of West Sumatra is located on the central Indian Ocean coast of the island of Sumatra. It is the traditional homeland of the Minangkabau people. This ethnic group differs from Indonesia's other cultures because it has an ancient matrilineal social system and customary kinship structures led by women (Sanday, 2003). Despite this, all Minangkabau people are Muslim and are considered conservative and strongly religious (Salim, 2013). Like other parts of Indonesia, the health-care system is part of the public context in West Sumatra. Despite excellent access to facilities, public dissatisfaction is high with major concerns over cost, lack of informed consent, the perception that doctors only care about making money, long waiting times and incompatibility of treatment with cultural and religious prerogatives (Fanany, 2013).

Within the health-care sector itself, hospital management is widely seen as impeding further quality improvement due to changes in the regulatory environment as well as to unclear and conflicting responsibility at different levels of government. The latter issue is significant in many parts of Indonesia, where it has also slowed hospital accreditation (Hort et al., 2013). In West Sumatra, hospitals have had difficulty achieving these standards, despite being above average in terms of facilities and personnel. Similarly, the province has often not met basic health standards and is below average on a number of basic measures, such as infant mortality rate and immunization levels (Ministry of Health, 2014). 


\section{Case studies of West Sumatran hospitals}

To better understand their management context, three cases studies of leadership were developed for hospitals that occupy different structural positions in the current health-care system. These hospitals have varying achievement levels on quality metrics and are run by different branches of the local government. Their characteristics are mentioned in Table I.

These different types of institutions reflect the dilemma of hospital management under regional autonomy; while all hospitals are regulated by the national healthcare system, their management processes and administrative responsibility vary because of the way decentralization has been implemented. Located in the provincial capital, Hospital A comes under the jurisdiction of the mayor. Approximately 70 per cent of its staff are employees of either the city government or the central government (depending on position and time of original employment). Hospital B, located in the Agam region, is under the direct authority of the governor; some of its staff are employees of the provincial government, while the rest are on contract to the hospital itself. Hospital $\mathrm{C}$ in the Solok region comes under the jurisdiction of the regency. Approximately 65 per cent of its staff are employed by either the central or local government, but hiring is at the discretion of the regent. Like the population of West Sumatra as a whole, virtually all staff at the three hospitals are Minangkabau people. As indicated in Table I 1 ich of these hospitals has had difficulty meeting relevant standards.

Semi-structured in-depth interviews with the director, senior management staff and a representative selection of employees in other categories were held at each hospital. These included the chief financial officer, head of medical services, two additional senior managers, five members of the medical committee and five members of the nursing staff at each location. Plain language statements outlining the nature and purpose of the study were provided to each interviewee. The interviews were carried out at the hospitals in the Indonesian language, although interviewees frequently switched to Minang, and intermittently used English words and terms. The interviews were digitally recorded, transcribed and translated by the authors. In addition, the hospitals provided documents for analysis and inclusion in this study. Ethics approval for this research was granted by the Faculty of Public Health of Universitas Andalas in Padang and was endorsed by the governing body of each hospital.

Following transcription, interview texts were analyzed using a process of thematic content analysis (Ritchie and Lewis, 2004; Pope and Mays, 2013) to identify areas of management where there might be conflict or contrast between local perceptions of leadership and the requirements of the national system. It has frequently been noted that the national system in Indonesia has been heavily influenced by the culture of the Javanese ethnic group, who make up 60 per cent of Indonesia's almost 250 million people (Vatikiotis, 1993; Nordholt, 2003; among others). In establishing its health-care system, Indonesia has increasingly relied on international standards (such as the US Joint Commission

\begin{tabular}{lcccr}
\hline Metric & Hospital A & Hospital B & Hospital C & National standard \\
\hline Bed occupancy rate (BOR) (\%) & 17.3 & 71.4 & 17.3 & $60-85$ \\
Bed turnover (BTO) (times/year) & 18.9 & 59.1 & 15.6 & $40-50$ \\
Average length of stay (ALOS) (days) & $6-9$ & 4.4 & 3.1 & 3.1 \\
Turnover interval (TOI) (days) & $<5$ & 1.8 & 19.2 & 15.1 \\
Gross death rate (GDR) (\%) & 14.4 & 5.9 & 24 & 4.5 \\
Net death rate (NDR) (\%) & 4.2 & 3.4 & 10.8 & 2.5
\end{tabular}

Source: Documents provided by participating hospitals
Effects of local culture

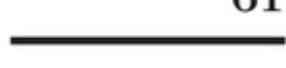


LHS

30,1

62

International Framework noted above), an approach that demands the type of management practices that underpin such standards.

The management and leadership concepts within the Indonesian national system, as well as those current in the international environment, are very different from the conceptualization of leadership of Minangkabau traditional culture. The attributes of leadership in this traditional model have been described by several authors (Navis, 1984; Hakimy, 1991; Fanany and Fanany, 2002), based on traditional Minang literature. Major principles of leadership and desirable characteristics for those in positions of authority were identified from these sources. The attributes of effective leadership in modern health-care settings have been rigorously investigated and reported in the literature (Forman et al., 2015). The themes of analysis were identified with reference to these two sets of leadership characteristics, highlighting actual and potential conflicts for further investigation.

\section{Findings}

Analysis of interview data indicates that hospital leadership and staff recognize several problematic areas. These are the administrative hierarchy; the decision-making process and delegation of responsibility. Both management and non-management staff agree that these are crucial in achieving hospital goals, which include providing effective, timely and appropriate care to patients; meeting Ministry of Health standards; and maintaining their accreditation and improving their quality ranking.

The director of Hospital A is a 46-year-old woman who grew up in West Sumatra. Her mother is Minangkabau, but her father is not. In the Minangkabau matrilineal social structure, she belongs to her mother's family and has a place in the traditional structure of the community. She is very experienced as a medical educator and head of a health center. She feels her current staff do not fully support her and recognizes that she has difficulty in communicating with them. She notes that medical personnel dominate the workplace, and relations between them and other staff can be contentious. She feels she has tried to take the opinions of staff into account in making decisions. However, by their own admission, many staff members do not attend meetings intended to discuss such issues. Once a decision is made, however, the director often receives complaints. She described this situation in Indonesian as follows:

In my workplace, I always seek consensus and agreement. Once everyone agrees and I have issued a directive, there are still people who protest. I often wait around for them to start a meeting, but they never appear, so of course we just have the meeting and when a decision is announced, they make a fuss. [Switches to Minang] "Why was I not included?" That's the kind of thing they say. [Translated from Indonesian].

She noted that she was losing confidence in the value of involving staff in decision-making. She noted in Indonesian:

What's the point of meeting if it only becomes a forum for quarreling?

This director viewed her own leadership style as formal and acknowledged that she was quite rigid. She expects staff to carry out their duties and that the hospital will run smoothly when she is absent. Speaking in Indonesian, she said:

I treat the people under me in a semi-military manner. Those who won't take orders can go ahead (and do what they want). Obviously, I work according to procedure.

Many members of staff view this director's manner negatively. For example, several individuals resented supervision of their work. One explained in Indonesian: 
The director should trust me to do the job I am responsible for. You can see yourself, like with this issue of land (for expansion of the hospital) that involved the local community, she immediately took over.

The director herself believes that these complaints are based on the staffs experience with her predecessor who was not very concerned about following regulations. She explained in Indonesian:

All that time, they were in a comfort zone. The comfort was like this, [switches to Minang] the director did what he wanted, the staff did what they wanted, [switches to Indonesian] so it was very comfortable, they really enjoyed it. When I got here, I have a Master's degree in Hospital Management, so of course I fixed everything up. There were a lot of strange things that [switches to Minang] I [switches to Indonesian] straightened out. It made them uncomfortable; it bothered them.

Hospital A is not meeting several of the Ministry of Health standards; in particular, BOR, BTO and ALOS remain far from the desired level. While many hospitals in West Sumatra experienced a significant increase in use when Jaminan Pemeliharaan Kesehatan Masyarakat (JPKM) was introduced in 2004, Hospital A did not, a situation its staff attribute to management and quality of care issues.

Hospital B's director is a 50-year-old woman. She is a medical doctor with a master's degree in public health. She views her leadership style as democratic and fair to those under her. She is hardworking and has a team of female deputies. She held similar positions at several other hospitals in West Sumatra and understands both health-care services and the cultural context. Her deputies and other hospital staff like her and see her as embodying the characteristics associated with female leaders in Minangkabau culture. In particular, the staff note the director's success in improving the overall situation at the hospital. One said in Indonesian:

In a short time, she was able to increase the hospital's revenue, bring in a maximal number of specialists, and raise our classification, all of which are indicators of a very good hospital.

When asked about these achievements, the director responded in Indonesian:

I have really tried to reach the targets set by the Ministry of Health and also, I am on a contract from the Governor. When my contract is up, they'll decide whether to extend my term or not.

The director further explained that she attributes her ability to get things done to her deputies, who are compatible because they are also Minangkabau women. Speaking Indonesian, she said:

Even if the director were away for, say, two months, the system should keep running. I have a solid team of deputies. We know and understand each other. It's different than in the past when my deputy was a man.

This director has experienced very little conflict between groups of staff. She has taken a strong position in disagreements between medical and other staff, which often result in discord, and has tried not to allow them to escalate. She described how she presents this to staff, saying in Indonesian:

For as long as you wear a civil servant's uniform, you will follow the rules that are in effect here. If you do not want to do that, then take off the uniform.

The director of Hospital B is particularly concerned about public perception of the hospital. For this reason, she has set up a system for patients to report any members of staff whom they feel have not treated them appropriately. This policy was not well received, particularly by the medical staff. One doctor noted in Indonesian:

How can the director get involved in these small things? Much less know whether a report [about us] is valid or not. This just creates internal problems among ourselves. 
LHS

30,1

64

Hospital B is larger than the other hospitals in this study and is generally meeting Ministry of Health standards. The presence of trusted deputies has likely contributed to the director's ability to improve quality and meet targets. Her management strategies are accepted by staff, and she has earned their respect.

The 53-year-old director of Hospital C is Balinese and male and has been working in West Sumatra for more than 20 years. He is a medical doctor with a master's degree in education. He first arrived here when he was appointed to a staff position at a public health center. His wife is Minang, and he feels he understands the local culture, despite it being very different from Bali, where he was raised. Having come up through the ranks to his current position, this director feels he is open and approachable and is always willing to meet with staff. Nonetheless, he admits he is often at a loss as to how deal with staff whom he sees have difficulty doing what he tells them to. He feels, however, that they are only pretending not to understand what they are told and really do know what he intends. He says his hands are tied, though, because he is not party to hiring decisions, which are made by the local government. He explained in Indonesian:

Ithink there should bea fit and proper test because people are appointed just like that. There was one section head who only lasted one day. He couldn't take it and resigned.

He went on to describe how these hiring practices interfere with his ability to get things done. He said in Indonesian:

Decisions about non-technical issues are often unconsidered, like when the regent appointed a head of the Medical Services Department who was not a doctor.

This director believes that some of the hospital's problems could be solved by more financial independence, and, for this reason, to have the hospital changed to a regional public service agency, which would allow more flexibility. Speaking in Indonesian, the director commented:

I am committed to becoming a regional public service agency so we can be freer. But my colleagues (who report to me) doubt the capacity of the hospital to achieve this because we don't have many patients.

The staff are against this change in status. One said derisively in Indonesian:

You can see the state of this hospital for yourself. How can it become a regional public service agency?

On a more personal level, the staff acknowledge that this director is intelligent but does not fit in well. They feel he does not trust them to do their work. The director knows this and explained his view in Indonesian as follows:

If I give someone a task and then it seems like that person is overloaded, I might give that work to someone else. It then turns out that the person I first gave the job doesn't like that decision which is intended to reduce their load. So, in the end, the work never gets done.

While admitting that many of his staff dislike him, the director of Hospital $\mathrm{C}$ feels he makes clear what is to be done and delegates tasks, which he expects, will be carried out. This is often not the case, however, and he believes that staff are unwilling to do anything they will have to take responsibility for. He described this in Indonesian:

Any time anything arises, like we need gas for the ambulances for example, they come to me. I feel like every problem comes to me. If the director has told someone to do something, then the staff shouldn't be worried about doing it, there should be nothing to be afraid of.

Reflecting on his experiences, the director recognizes serious communication problems that contribute to the issues he has had to deal with. He commented in Indonesian: 
I often wonder if I misspoke because people often don't get what I mean.

Not surprisingly, the director finds this very frustrating. He went on:

They're adults, and I shouldn't have to supervise important work that has a deadline. Every time I tell someone to do something or request data, it is extremely difficult. It always gets put off and is not done by the deadline.

Despite the director's belief that he understands his staff and the community, there are significant management problems at Hospital C, and even the director acknowledges the problems in getting things done. This has contributed to performance on the Ministry of Health standards and work environment that is unpleasant for both staff and management. It is notable that this director comes from another part of Indonesia that has a very different social structure, language and culture, which may contribute to the difficulties at the hospital.

\section{Discussion}

Each of the three hospitals has experienced problems in leadership that were recognized by both staff and management. The local government administration responsible for each of the hospitals is also aware of this. Investigation into the nature of leadership at each institution highlighted conflicts between the traditional model of leadership in the Minangkabau culture of the majority of staff and the demands of the national health-care context, which is structured according to international norms that come from Western contexts.

One significant area of discord in the hospital environment is the decision-making process and resolution of differences. While the national system is structured hierarchically, leaders in Minangkabau culture are viewed as only one step above the people below them. A well-known proverbial expression states that a leader should be "raised one twig higher, advanced one step ahead" of others. This slight difference in status accounts for the traditional pattern of decision-making that places a strong emphasis on consensus and agreement from all members of the group. This is the way extended families function in the traditional context. There is also a corresponding idea that quarreling and differences of opinion support better outcomes. This idea is contained in the proverb "When the sticks are crossed in the stove, only then will the fire catch". The crossed sticks refer to different views that should be argued out. The expectation that every person at a meeting or discussion will have a chance to speak and that quarrelling is not negative likely contributes to the difficulty the hospital directors quoted above have in managing meetings and getting staff to accept their decisions. Traditional forms of interaction do not fit with the tight schedules and rigid procedures of the health-care environment that do not allow adjustment.

Minangkabau culture traditionally has a tripartite leadership structure composed of experts in traditional law and culture, religious scholars and intellectuals. These three groups should play equal roles in society, as in the proverb "Trivets necessarily come in threes", which requires that all three elements be present for the community to function. In the modern context, however, the status of people with a professional education is much higher than that of other groups because of the prestige of the institutions where they work. This contrasts with the traditional context and often results in problems between medical staff and other employees, who are not willing to treat doctors, and especially specialists, in the way these professionals feel they are entitled to. For example, doctors at the hospitals in this study felt they should be allowed to come and go as they pleased without their attendance being monitored, even though this practice is usual for other staff.

As noted, the Minangkabau culture is matrilineal, and senior women head the extended family and clan. This may explain why a large number of women hold senior positions in many workplaces, and their status is well accepted by staff. In this study, this was notable in Hospital $\mathrm{B}$ where the female director has several deputies who are also women. This replicates the 
LHS

30,1

extended family structure and may be more familiar to staff who have been socialized in a context where responsibility lies with older women. This contrasts particularly with Hospital C whose director is male and comes from another ethnic group. Hospital C's director experiences considerable problems in communication, which likely reflect his linguistic and cultural background. This background makes him an outsider among other staff. In-group membership often aligns with language. Code-switching between Minang and Indonesian occurred in the interviews as a linguistic strategy used by the directors of Hospitals A and B to signal the in-group status of the interviewer, who is a Minangkabau woman and a medical doctor.

A prominent issue at all three hospitals, which is seen by directors as impeding the achievement of required outcomes, relates delegation of responsibility, and especially staff refusal to accept the need for oversight and supervision. Again, this may relate to the Minangkabau cultural model that suggests "A grant must be vacated", which suggests that a responsibility given to someone to handle must be left to that person without further interference or questioning. In this light, the need for various tasks to be checked by supervisors, including the director of the hospital, may be taken as a sign of distrust by staff and resented, as the directors indicated. This may contribute to the extreme caution among staff reported by the director of Hospital C.

The fact that traditional culture includes a model of leadership unlike that required in the national context does not necessarily mean that staff do not understand or are unwilling to comply with institutional norms. However, it is the case in West Sumatra that a large majority of the public comes from the same ethnic group and speaks the same language. For this reason, the distinction between the public, formal environment and the traditional, informal context is often blurred. All the individuals interviewed here, for example, spoke Indonesian fluently, as is required for success in formal education leading to a professional qualification. However, as occurs all over Indonesia, many feel more comfortable with Minang, which also reinforces ethnic identity and group membership. Despite having been educated in Indonesian, the national language remains a second language associated with specific formal contexts for most people. It is the cognitive framework of a person's first language that usually defines interpretations that are more integral to individual experience. Because so many people in West Sumatra have the same background, the need to use Indonesian and its accompanying cultural model is less pressing.

The experience of staff and management at the three hospitals exemplifies the situation across Indonesia. The modern national structures form a stratum that overlies numerous, much older, traditional institutions. This very complex cultural and linguistic context contrasts with the demands of modern health care. For this reason, the nature of the society that is served by institutions like hospitals must be considered in developing leadership practices that derive from these contexts and can potentially achieve the aims of the national system. The adoption of Western models may not be effective for this, as they derive from outside cultural practices. Instead, health care in Indonesia would benefit greatly from more rigorous study of the unique aspects of the many cultures that structure the perceptions and expectations of the public and act as a counter-influence to the external influences that shape many modern institutions.

\section{References}

Fanany, R. (2013), "Health and health care under regional autonomy in West Sumatra, Indonesia", Surindra Journal of Local Development, Vol. 6 No. 1, pp. 25-42.

Fanany, R. and Effendi, Z.M. (1999), "Minangkabau children to Indonesian adults: promoting public policy through Indonesian language teaching in West Sumatra, Indonesia", Crossroads: An Interdisciplinary Journal of Southeast Asian Studies, Vol. 13 No. 1, pp. 105-113. 
Fanany, R. and Fanany, I. (2002), "The ties that bind: leadership and its responsibilities in Minangkabau proverbs", Proverbium, Vol. 19, pp. 99-112.

Forman, D., Jones, M. and Thistlethwaite, J. (Eds) (2015), Leadership and Collaboration: Further Developments for Interprofessional Education, Palgrave Macmillan.

Hakimy, H.I. (1991), Pegangan Penghulu, Bundo Kanduang, Dan Padato Alua Pasambahan Adat Di Minangkabau, PT Remaja Rosdakarya, Bandung.

Hort, K., Djasri, H. and Utarini, A. (2013), "Regulating the quality of health care: lessons from hospital accreditation in Australia and Indonesia", The Nossal Institute for Global Health, Working Paper Series 28.

Joint Commission International (2015), About JCI, Joint Commission International, Oakbrook, OH, available at: www.jointcommissioninternational.org/about/ (accessed 29 December 2015).

Komisi Akreditasi Rumah Sakit (KARS) (2015), Visi dan misi KARS, KARS, Jakarta, available at: www.kars.or.id/?page_id =60 (accessed 28 December 2015).

Kristiansen, S. and Santoso, P. (2006), "Surviving decentralisation?: impacts of regional autonomy on health service provision in Indonesia”, Health Policy, Vol. 77 No. 3, pp. 247-259.

Meliala, A., Hort, K. and Trisnantoro, L. (2013), "Addressing the unequal geographic distribution of specialist doctors in Indonesia: the role of the private sector and effectiveness of current regulations", Social Science \& Medicine, Vol. 82, pp. 30-34.

Ministry of Health, Republic of Indonesia (2014), Laporan Akuntabilitas Kinerja Kementerian Kesehatan tahun 2013, Ministry of Health, Jakarta.

Navis, A.A. (1984), Alam Takambang Jadi Guru, PT Gramedia, Jakarta.

Nordholt, H.S. (2003), "Renegotiating boundaries: access, agency and identity in post-Soeharto Indonesia”, Bijdragen tot de Taal, land-en Volkenkunde, Vol. 159 No. 4, pp. 550-589.

Pope, C. and Mays, N. (Eds) (2013), Qualitative Research in Health Care, John Wiley \& Sons.

Ritchie, J. and Lewis, J. (2004), Qualitative Research Practice, Sage, London.

Salim, D.P. (2013), "Islam, politics and identity in West Sumatra", Journal of Indonesian Islam, Vol. 7 No. 1 , pp. 96-118.

Sanday, P.R. (2003), Women at the Center: Life in a Modern Matriarchy, Cornell University Press, Ithaca, NY.

Sukarni, M. (1994), Kesehatan keluarga dan Lingkungan, Penerbit Kanisius, Yogyakarta.

Tjiptoherijanto, P. and Soesetyo, B. (1994), Ekonomi Kesehatan, Rineka Cipta, Jakarta.

Trisnantoro, L. (2001), "Perubahan sistem kesehatan wilayah akibat kebijakan desentralisasi”, Jurnal Managemen Pelayanan Kesehatan, Vol. 4 No. 2, pp. 93-100.

Vatikiotis, M.R. (1993), Indonesian politics under Suharto, Routledge, London.

\section{Corresponding author}

Rebecca Fanany can be contacted at: rebecca.fanany@deakin.edu.au

For instructions on how to order reprints of this article, please visit our website:

www.emeraldgrouppublishing.com/licensing/reprints.htm

Or contact us for further details: permissions@emeraldinsight.com 
The effects of local culture on hospital administration in West Sumatra, Indonesia

ORIGINALITY REPORT

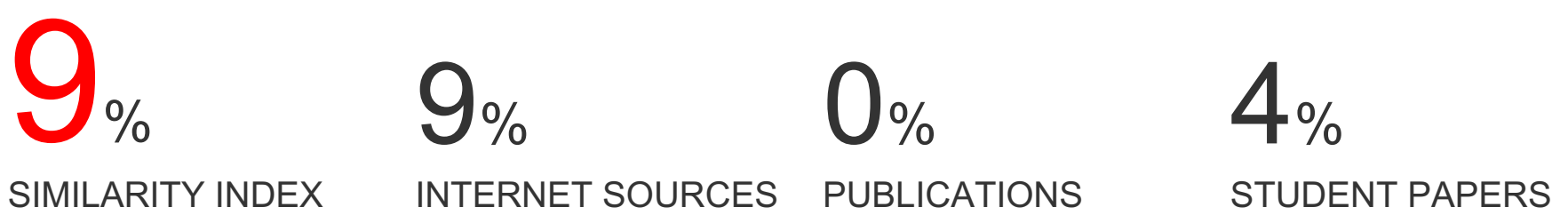

PRIMARY SOURCES

1 www.emerald.com

Internet Source

$6 \%$

2 www.escience.cn

Internet Source

$4 \%$

\section{Exclude quotes}

On

Exclude bibliography

On
Exclude matches

$<3 \%$ 